Vol. 8 No. 2 (Juli-Desember) 2021

ISSN: 2355-7982|E-ISSN:2622-5115

http://jurnal.uinsu.ac.id/index.php/komunika

\title{
Hijrah Sebagai Gaya Hidup Generasi Digital Native Urban
}

\author{
Sukma Ari Ragil Putri \\ Komunikasi dan Penyiaran Islam, IAIN Tulungagung \\ sukmaariragilputri@gmail.com
}

\begin{abstract}
This study was conducted to analyze a person's communication experience in interaction with their social group, namely the hijrah community in a big city. This study uses a qualitative design with a phenomenological approach. The concepts of Group Communication and Symbolic Interactionism are used in discussing phenomena that arise as a result of the informant's experience. The results of this study indicate that in the hijrah communication process, informants received positive responses from the social environment, although in the process of interaction with the hijrah community they led to groupthink, but the level was still moderate. In addition, the adoption of hijrah as a lifestyle was also experienced by informants by showing it symbolically in the form of clothing, language, and life choices.

Keywords: Hijrah; Lifestyle; Urban
\end{abstract}

\begin{abstract}
Abstrak: Penelitian ini dilakukan guna meneliti dan menganalisa pengalaman komunikasi seseorang dalam interaksi dengan kelompok sosial mereka yaitu komunitas hijrah di kota besar. Penelitian ini menggunakan desain kualitatif dengan pendekatan fenomenologi. Konsep Komunikasi Kelompok dan Interaksionisme Simbolik digunakan dalam membahas fenomenafenomena yang muncul sebagai hasil dari pengalaman informan. Hasil penelitian ini menunjukkan bahwa dalam proses komunikasi hijrahnya, informan mendapat tanggapan positif dari lingkungan sekitar, meskipun pada proses interaksi dengan komunitas hijrah mereka mengarah pada groupthink, namun tarafnya masih moderat. Selain itu pengadopsian hijrah sebagai gaya hidup juga dialami oleh informan dengan cara menunjukkan secara simbolis dalam bentuk pakaian, bahasa, dan pilihan hidup.
\end{abstract}

Kata kunci: Gaya hidup; Hijrah; Urban

\section{PENDAHULUAN}

Gaya hidup merupakan karakteristik masyarakat urban atau masyarakat modern, maksudnya adalah manusia yang hidup dalam masyarakat modern akan menggunakan gaya hidup sebagai parameter untuk menggambarkan perilakunya sendiri dan orang lain. Gaya hidup sendiri dimaknai sebagai pola-pola perilaku yang kemudian menjadi penciri antara satu orang dengan orang lain. Dalam kehidupan sehari-hari, kita dapat dengan mudah menangkap gagasan mengenai gaya hidup seseorang atau kita sendiri namun mungkin sulit untuk menemukan definisi umum mengenai hal-hal apa saja yang merujuk pada gaya hidup. Menurut David Chaney, gaya hidup dapat menjadi parameter manusia dalam memahami orang lain, apa yang mereka lakukan, mengapa, dan apakah yang mereka lakukan memiliki makna bagi dirinya dan orang lain (Chaney, 1996).

Era globalisasi memiliki peranan penting dalam struktur gaya hidup masyarakat modern. Saat ini era global telah mengaburkan batas-batas budaya lokal, nasional, maupun regional. Hal ini kemudian membawa perubahan yang signifikan pada gaya hidup dimana arus gelombang gaya hidup global kemudian dengan mudah berpindah tempat dengan perantara media massa. Terlihat dari maraknya Japanese Style dan Korean Style dua dekade terakhir. Gaya hidup kemudian memberikan penawaran akan rasa identitas sekaligus sarana untuk menghindarkan manusia dari kebingungan karena tersedianya banyak pilihan akibat globalisasi (Adlin, 1997). 
Perubahan gaya hidup yang telah masuk dalam sistem globalisasi juga terjadi di Indonesia beberapa dekade terakhir, khususnya gaya hidup yang berkaitan dengan subkultur keagamaan. Fenomena ini berlangsung beberapa tahun terakhir dimana gairah keIslam-an masyarakat di Indonesia memang mulai meningkat. Sederhananya dapat dilihat dari gaya hidup masyarakat muslim Indonesia di beberapa periode. Indonesia di bawah pemerintahan Presiden Suharto, merupakan negara cukup kaku dalam penerapan beberapa aturan, salah satunya aturan dalam beragama. Pemerintah secara tidak langsung membatasi penggunaan jilbab ataupun gerakan ke arah Islam yang dianggap radikal dengan cara mempersulit penggunaan jilbab di sekolah-sekolah. Era orde baru yang menjunjung kestabilan politik, ekonomi, dan pertananan keamanan, berusaha untuk 'meluruskan' agama-agama atau aliran-aliran yang dianggap terlalu ke kiri atau terlalu ke kanan. Salah satunya adalah dengan dikeluarkannya SK Dirjen Dikdasmen No. 52 tahun 1982 yang berbunyi bahwa jika terdapat siswi yang mengenakan jilbab, maka keseluruhan siswi harus mengenakan jilbab atau tidak sama sekali (Nurlatifah, 2019).

Bandingkan dengan kondisi saat ini dimana bahkan penggunaan cadar pun dianggap sebagai sesuatu yang lumrah bahkan menuai dukungan dari masyarakat. Hasil survey Lembaga Survei Kelompok Diskusi dan Opini Publik Indonesia (KedaiKOPI) menyatakan $63,3 \%$ responden percaya mereka yang bercadar tidak berafiliasi dengan kelompok radikal (Wijaya, 2018). Hal ini menunjukkan perubahan paradigma masyarakat Indonesia yang tadinya di awal 2000an sempat mengidentifikasi cadar sebagai muslim kelompok radikal maka sekarang telah bergeser. Jika sebelumnya masyarakat di Indonesia sifatnya lebih 'umum' dan cenderung kebarat-baratan, misalnya penggunaan hijab yang sederhana dipadu dengan jeans dan kaos, saat ini yang tengah populer adalah yang syar'i, dengan menggunakan gamis dan jilbab lebar dan panjang menutup dada karena telah melalui proses hijrah. Data dari Badan Pusat Statistik sendiri pada 2016 menunjukkan sebanyak 47\% perempuan muslim di Indonesia telah berjilbab (Asrianti, 2019).

Hijrah disini diasosiasikan dengan perubahan kepada yang lebih baik. Hijrah sendiri pada dasarnya ada dua jenis, hijrah jasmani dan hijrah rohani (Meiranti, 2019). Hijrah jasmani merupakan hijrah secara literal, yaitu perpindahan dari satu tempat ke tempat lain yang merujuk pada hijrah yang dilakukan Nabi Muhammad SAW dan pengikutnya dari Mekah ke Madinah pada tahun 611. Sedangkan hijrah rohani didefinisikan sebagai mendekatkan diri dengan kebiasaan-kebiasaan yang baik dan meninggalkan dosa-dosa dan kesalahan terdahulu. Hijrah tidak harus berpindah secara fisik akan tetapi dalam kehidupan sehari-hari menjauhi perilaku maksiat dan kemungkaran, menjauhi orang-orang dzolim dan berakhlak buruk juga merupakan bentuk hijrah.

Penelitian yang dilakukan oleh Distrian Rihlatus Sholihah (Sholihah, 2019) mengungkapkan bahwa makna hijrah sendiri pada zaman sekarang sangat berbeda dengan makna hijrah secara harfiah, dimana hijrah saat ini dimaknai dan dikontekstualisasikan dalam tren hijrah muslim millennial dengan segala atributnya. Lebih lanjut lagi pemaknaan hijrah saat ini seringkali dikaitkan dengan gerakan hijrah yang dipelopori oleh public figure yang mengikuti kajian serta perlaku ekonomi yang mulai meningkatkan penjualan pakaian dan atribut hijrah (Fajriani, 2019). 
Fenomena hijrah ramai terjadi pada muslim urban, khususnya yang di daerah ibukota Indonesia dan sekitarnya karena terdapat pengaruh yang kuat dalam kaitannya dengan pergaulan di Jakarta. Masyarakat di perkotaan memiliki akses telekomunikasi yang memadai, terutama akses internet. Berdasarkan data yang dikemukakan oleh Badan Pusat Statistik (BPS) terdapat peningkatan signifikan presentase masyarakat yang mengakses internet dalam kurun waktu lima tahun terakhir. Sebanyak 50,92 persen masyarakat perkotaan dan 26,56 persen masyarakat pedesaan mengakses internet pada tahun 2018 (Susanti, 2020).

Dari prosentase tersebut, sebanyak 67,02 persen adalah digital native, yaitu mereka yang lahir dan tumbuh dewasa dalam lingkungan digital dengan fasilitas internet. Digital native saat ini mencakup penduduk Indonesia yang berusia 15-35 tahun. Sedangkan sisanya merupakan digital immigrant, yang seperti halnya kaum pendatang atau imigran, penduduk usia 36-54 tahun ini merupakan penduduk yang mencoba belajar mengadopsi teknologi baru di kehidupannya (Hariyani, 2017).

Jika diamati, hijrah di Indonesia saat ini terjadi secara rohani pada muslim kelas menengah ke atas di daerah perkotaan. Dikatakan demikian karena campaign soal hijrah sendiri paling massif dilakukan di media sosial dimana sesuai data sebelumnya bahwa pengguna internet terbesar adalah digital native yang tinggal di perkotaan. Masyarakat perkotaan, khususnya di Jakarta, merupakan masyarakat yang individualis. Salah satu karakteristik masyarakat perkotaan adalah mereka pada umumnya dapat mengurus dirinya sendiri tanpa bergantung pada orang lain. Yang terpenting adalah manusia perseorangan atau individu (Jamaludin, 2015).

Seperti kita tahu, Jakarta merupakan kota yang sangat besar, dimana jarak antar lokasi cukup jauh, belum dengan adanya kemacetan yang seolah sudah menjadi langganan sehari- hari. Setiap harinya masyarakatnya harus menempuh jarak tertentu untuk bekerja dengan waktu tempuh yang sangat menyita waktu. Sebagai gambaran jarak tempuh Kabupaten Trenggalek ke Kabupaten Tulungagung kurang lebih $32 \mathrm{~km}$ dan bisa ditempuh dalam waktu 45-60 menit. Sedangkan di kota besar, sebagai contoh jarak tempuh Bekasi ke Jakarta Selatan yaitu $25 \mathrm{~km}$ dan bisa ditempuh dalam waktu 60 menit lewat tol. Jika tidak lewat tol maka akan lebih lama lagi waktu tempuhnya. Dengan kondisi seperti itu, maka waktu yang dimiliki oleh masyarakat perkotaan untuk melakukan kegiatan lain selain bekerja sangat terbatas, pun untuk bersosialisasi, apalagi belajar agama pada kyai selayaknya masyarakat pinggiran. Sosialisasi yang mereka lakukan mayoritas melalui ponsel pintar, karena seperti kita tahu segala sesuatu bisa dilakukan dengan adanya ponsel pintar. Tak terkecuali belajar agama.

Kampanye hijrah yang massif dilakukan di media sosial kemudian menjadi salah satu opsi bagi masyarakat perkotaan untuk belajar agama. Hal ini kemudian diikuti oleh munculnya ustaz-ustaz yang mengakomodir kebutuhan masyarakat perkotaan dengan melakukan dakwah di media sosial. Ustaz-ustaz tersebut kemudian memfasilitasi masyarakat kota yang hanya punya sedikit waktu untuk belajar agama dengan menawarkan Islam yang 'ready-to-use' atau yang kita kenal dengan Islam popular saat ini (Widhana, 2019). Yaitu, Islam yang instan, dekat dengan mereka, tidak rumit, dan tidak memunculkan 
kebimbangan. Misalnya saja soal hukum memakai jilbab, jika ditanyakan kepada para kyai atau ulama seperti Muhammad Quraish Shihab, beliau pasti akan menjelaskan berbagai pilihan hukum yang membebaskan kita untuk memilih. Namun jika ditanyakan kepada kelompok yang menggaungkan hijrah misalnya pada Ustaz Khalid Basalamah, maka jawabnya akan singkat saja; hukumnya wajib.

Pun dalam hal mengkaji isi Al-Qur'an, masyarakat perkotaan kemudian difasilitasi dengan berbagai program seperti NGEFAST, sebuah platform yang menawarkan kelas belajar agama secara daring dan luring dengan sebutan KEY (Kelas Eksekutif \#YukNgaji) yang menawarkan penguasaan agama meliputi empat aspek, yaitu aqidah, hijrah, sejarah, dan dakwah selama 16 kali pertemuan atau sekitar 16 minggu (Aurelia, 2019). Dalam waktu sesingkat itu, belajar agama tentunya tidak bisa dikatakan menyeluruh, sehingga yang diajarkan pun sesuai dengan kebutuhan masyarakat kota yang membutuhkan ajaran agama yang tidak rumit dan cenderung instan. Bandingkan dengan misalnya Quraish Shihab yang harus menempuh waktu puluhan tahun untuk belajar agama sejak dari pesantren hingga perguruan tinggi agama (Widhana, 2019).

Penyebab lain hijrah menjadi fenomena yang tidak terelakkan di kalangan menengah ke atas kota besar adalah fakta bahwa berhijrah membutuhkan biaya. Perubahan penampilan misalnya, butuh biaya yang tidak sedikit. Harga baju, jilbab, dan pakain lain yang tersebar di media online bisa dikatakan cukup mahal dan hanya bisa dikonsumsi oleh masyarakat menengah ke atas. Hal ini tidak terlepas dari pengaruh artis-artis ibukota yang kemudian memanfaatkan momentum hijrah mereka sebagai ajang terjun ke industri perdagangan, yang tentu saja menjadi tolak ukur tren masyarakat Indonesia khususnya masyarakat perkotaan. Belum lagi program belajar agama seperti NGEFAST yang tentunya memiliki biaya tertentu dengan sebutan infaq, mengingat lokasinya biasanya di tempattempat dengan fasilitas seperti AC, tempat bermain anak, dan sebagainya. Hal ini berbeda dengan program religi atau komunitas-komunitas religi yang umum ada di masyarakat yang tidak menuntut adanya commitment fee (Yasya \& Nurhaliza, 2021). Alasan-alasan itulah yang kemudian membuat hijrah saat ini dilakukan oleh masyarakat perkotaan kalangan menengah ke atas.

Edward T. Hall menyatakan bahwa "Communication is culture and culture is communication" (Hall, 1989). Komunikasi dan budaya memiliki hubungan timbal balik. Komunikasi manusia ditentukan dan dikembangkan menurut karakteristik budayanya. Dalam kaitannya dengan fenomena hijrah sebagai gaya hidup, komunitas hijrah yang terikat dan berinteraksi dengan sesamanya dapat menunjukkan karakteristik yang unik, mereka dapat menciptakan dunianya sendiri, struktur sosialnya sendiri, termasuk simbol dan proses komunikasinya (DeVito, 2008).

Menurut Hall komunikasi selalu dipahami orang hanya sebagai sebuah proses transmisi pesan dari komunikator kepada komunikan. Hai ini terjadi karena orang menganggap komunikasi sebagai sebuah perpindahan pesan dari komunikator kepada komunikan. Komunikasi sebagai sebuah transmisi selalu didefinisikan sebagai mengirim, memindah, atau memberi informasi kepada orang lain. Ia kemudian mulai mengkritisi model transmisi dan memberikan pandangan alternatif yaitu model ritual. Menurutnya, 
dalam perspektif ritual, komunikasi berkaitan dengan berbagi, partisipasi, perkumpulan/asosiasi, persahabatan, dan kepemilikan akan keyakinan iman yang sama (Hall, 1989)

. Pendekatan interaksionisme simbolik dapat digunakan untuk memahami bagaimana pelaku hijrah berinteraksi dengan komunitas barunya. Apa yang ditampilkan oleh pelaku hijrah dalam mendorong komunitas barunya bisa menerima dan memberikan respon yang diinginkan melalui bahasa verbal dan non verbal penuh dengan simbol-simbol khas. Dari sisi seorang pelaku hijrah motivasi atau upaya yang dilakukan dalam memerankan diri mereka sebagai seorang yang memiliki kontruksi identitas dan perilaku yang baru menjadi menarik untuk diteliti. Selain karena standar sosial yang mereka miliki, upaya menjadikan hijrah sebagai gaya hidup juga dimaknai bisa membantu mereka untuk mendapatkan posisi dan penerimaan yang lebih baik dalam lingkungan sosial. Adanya keyakinan bahwa status sosial adalah suatu pandangan natural yang membuat mereka lebih diyakini dan dipertimbangkan dalam segala hal memperkuat motivasi seseorang untuk mengusahakan mendapat status sosial yang lebih tinggi (Frank \& Riggins, 1992).

Berdasarkan sejumlah permasalahan tersebut, menarik untuk dikaji bagaimana gaya hidup, status sosial, dan interaksi sosial berkaitan dengan pengalaman hijrah seseorang. Peneliti menganggap hal tersebut penting karena bisa menjadi sebuah dasar dan gambaran mengenai fenomena yang sedang marak di masyarakat tersebut.

\section{METODE}

Penelitian ini merupakan penelitian kualitatif dengan menggunakan paradigma interpretif. Pendekatan penelitian interpretif memiliki sederet asumsi subjektivis tentang pengalaman nyata dan tatanan sosial (Crozier et al., 1994). Pendekatan tersebut adalah salah satu upaya membangun fenomenologi sosial yang mengaitkan sosiologi dengan fenomenologi filosofisnya. Yang utama adalah bahwa ilmu pengetahuan selalu berpijak pada yang eksperensial (yang bersifat pengalaman). Edmund Husserl (Crozier et al., 1994) mengemukakan bahwa hubungan antara persepsi dan objek-objeknya tidaklah pasif. Bahwa kesadaran manusia secara aktif mengandung objek-objek pengalaman.

Fenomenologi sosial yang diperkenalkan oleh Alfred Schutz ini dimaksudkan untuk merumuskan ilmu sosial yang mampu 'menafsirkan dan menjelaskan tindakan dan pemikiran manusia' dengan cara menggambarkan struktur-struktur dasar sehingga pendekatan interpretif fenomenologi sosial memusatkan pada makna dan pengalaman subjektif sehari- hari, yang bertujuan untuk menjelaskan bagaimana objek dan pengalaman terciptakan secara penuh makna dan dikomunikasikan dalam kehidupan sehari-hari (Crozier et al., 1994).

Perolehan data penelitian dalam penelitian ini menggunakan sumber data berupa hasil observasi dan wawancara subjek penelitian. Selain itu penelitian ini juga menggunakan sumber data literatur atau kepustakaan. Informan dalam penelitian ini dipilih dengan menggunakan purposive sampling, dimana objek penelitian yang dipilih adalah yang menguasai permasalahan (key informant). Subjek ini dipilih mengacu pada representativitas data atau informasi. Setiap subjek mewakili dirinya sendiri. Subjek dalam 
penelitian ini adalah dua orang muslim perempuan. Karakteristik informan yang diwawancarai adalah muslim yang bertempat tinggal di Jakarta, terlibat secara aktif dengan komunitas hijrah, memiliki media sosial, dan berusia sesuai kategori digital native yaitu 18-35 tahun.

Teknik analisis data yang digunakan adalah analisis data kualitatif dengan menggunakan penyederhanaan pendeketan dari Stevick-Colaizzi-Keen (Creswell, 1998) melalui proses sebagai berikut; 1) Deskripsi pengalaman personal informan mengenai awal mula proses hijrah hingga motivasi berhijrah, 2) Mengembangkan seperangkat daftar pertanyaan signifikan dan dikategorikan menjadi tema-tema disebut dengan deskripsi tekstural, 3) Mendeskripsikan pengalaman informan selama berhijrah dan kaitannya dengan social climbing yang kemudian disebut dengan deksripsi struktural yang berisi bagaimana gambaran setting dan konteks dalam fenomena yang dialami, 4) Melakukan deskripsi gabungan antara deskripsi tekstural dan deskripsi struktural. Pada penelitian ini hasil akan dijelaskan secara deskriptif gabungan langsung.

\section{HASIL DAN PEMBAHASAN Pengalaman Hijrah}

Pengalaman dapat dimaknai sebagai sesuatu yang dialami oleh seseorang. Berbicara mengenai pengalaman hijrah sama dengan berbicara mengenai pengalaman komunikasi. Karena dalam proses hijrah itu sendiri, seseorang melakukan proses komunikasi baik intrapersonal, interpersonal maupun kelompok sekaligus melalukan proses komunikasi atas identitas barunya setelah melewati proses hijrah. Hal ini sesuai dengan pernyataan Moustakas (Wirman, 2016) yaitu, "all objects of knowledge must conform to experience" semua objek pengetahuan harus sesuai dengan pengalaman. Kesadaran yang membentuk pemaknaan inilah yang mendorong individu untuk melakukan tindakan atau perilaku tertentu. Schutz (Wirman, 2016) mengatakan bahwa perilaku merupakan pengalaman kesadaran yang memberikan makna melalui aktivitas spontan.

Pengalaman yang diperoleh oleh seseorang selama proses komunikasi berlangsung mengandung informasi atau pesan tertentu. Informasi inilah yang kemudian akan diolah menjadi pengetahuan. Suatu peristiwa yang mengandung unsur komunikasi akan menjadi pengalaman komunikasi tersendiri bagi individu dan pengalaman komunikasi yang dianggap penting akan menjadi pengalaman yang paling diingat dan memiliki dampak khusus bagi individu tersebut (Wirman, 2016).

Semua informan dalam penelitian ini merupakan seorang digital native yang aktif di berbagai platform media sosial. Keduanya berusia 30an awal dan sama-sama tergabung dalam komunitas hijrah yang cukup populer yaitu Vision99, yang dilansir dari media sosialnya merupakan sebuah komunitas hijrah dengan puluhan ribu pengikut dan aktif melakukan kajian dalam komunitas mereka yang salah satu pengurusnya adalah public figure Chacha Frederica, yang juga merupakan sepupu dari informan I.

AFA seorang ibu rumah tangga yang sebelumnya bekerja di salah satu perusahaan multinasional selama kurang lebih enam tahun, menjelaskan bahwa awal mula dia berhijrah 
adalah dengan mengikuti kajian-kajian yang diselenggarakan oleh sepupunya, yang kemudian berkembang dengan dia mengikuti program yang diselenggarakan oleh komunitas Vision99 yaitu NGEFAST pada 2019, yang berbentuk pelatihan atau kajian intensif tentang dasar-dasar Islam dan menjadi muslim. Program ini memiliki online presence tinggi dan tersebar di berbagai daerah di Indonesia. NGEFAST tidak melabeli diri sebagai pengajian tetapi lebih kepada training dan pemateri disebut sebagai trainer.

"Jadi awalnya tu karena diajakin kajian sama Chacha kan terus ya mulai dari situ ikut kajian-kajian lain yang diselenggarain sama Vision99 terus akhirnya ikutan NGEFAST. Ketemu deh sama peserta-peserta lain yang rata-rata seumuran, jadi kayak santai gitu acaranya makanya akhirnya terus ada di komunitas ini. Ustadznya juga disebutnya trainer jadi kita kayak lebih santai aja mau berinteraksi ga yang malu atau ga nyaman gitu." (AFA 2021, wawancara, tanggal 8 November 2021)

AFA menjelaskan bahwa pengalaman awal yang dia dapatkan dari mengikuti kajian menjadi landasan baginya untuk melakukan tindakan selanjutnya yaitu mengikuti program NGEFAST dan berlanjut masuk ke komunitas Vision99. Hal ini sejalan dengan pernyatan dari Radford (Wirman, 2016) yaitu bahwa manusia mengambil ingatan tertentu dari fenomena yang dia alami sebelumnya untuk pertimbangan perilaku selanjutnya. Saat ini AFA tergabung dalam komunitas 'imanpath' yang digawangi oleh Ustadz Faris BQ. Bersama dengan suaminya, AFA tergabung dalam tim kreator 'imanpath' sebagai video and content creator.

Senada dengan AFA, informan kedua, VS, adalah seorang ibu rumah tangga yang aktif di media sosial dan tinggal di Tangerang Selatan. VS memulai pengalaman hijrahnya dari mengikuti kajian-kajian Vision99 yang kemudian berlanjut pada keikutsertaannya dalam program NGEFAST bersama dengan AFA. Salah satu motivasi yang mendasari dia untuk mengikuti kajian-kajian dan berhijrah adalah adanya ajakan dari inner circle-nya yaitu saudaranya sendiri. Motivasi seseorang dalam melakukan tindakan tertentu menunjukkan adanya hubungan sistematik antara respon dengan keadaan dorongan untuk melakukan sesuatu (Ahmadi, 2009).

“...iya kan karena diajakin sama Dea waktu itu terus akhirnya ikutan NGEFAST, mulai dari situ gue akhirnya kayak yang apa ya, bisa dibilang hijrah juga sih, pake kerudung, terus gue resign juga waktu itu, dan masuk ke circle yang memang sering ketemunya sama orangorang komunitas sih kak." (VS 2021, wawancara, tanggal 9 November 2021)

Motivasi manusia merupakan dorongan dari keinginan dan tenaga penggerak lainnya untuk melakukan sesuatu. Semua tingkah laku manusia pada dasarnya memiliki motif, yang mana motif itu sendiri muncul karena adanya respon dari dorongan yang ada dalam diri manusia itu sendiri. Dorangan yang dimaksud bisa didapat dari merespon stimulus yang diberikan oleh lingkungan sekitar, dalam penelitian ini yaitu dari orangorang terdekat informan yang kemudian menumbuhkan motivasi para informan untuk melakukan hijrah.

Selain itu, motif umumnya muncul karena adanya kebutuhan atau needs (Ahmadi, 2009). Situasi membutuhkan sesuatu ini kemudian menjadi dorongan untuk menyebabkan seseorang kemudian berusaha untuk memenuhi kebutuhan tersebut. Hal ini tampak pada pernyataan AFA mengenai pemenuhan kebutuhan batinnya.

“...gue tu kan udah nikah, udah punya anak juga, kerja juga udah oke waktu itu, kayak yang apalagi ya yang kurang, gue masih butuh apalagi gitu, akhirnya gue ngobrol-ngobrol 
sama adek gue kan waktu itu, Icha, dan kita kayak yang apa kita udah waktunya pake kerudung ya dek, kayak apalagi yang mau ditunggu gitu." (AFA 2021, wawancara, tanggal 8 November 2021)

Informan AFA dan VS sama-sama memiliki pengalaman komunikasi yang positif selama proses berhijrah. Selain mereka mendapatkan pengertahuan-pengetahuan baru mengenai agama mereka selama proses berhijrah, mereka juga berhasil untuk mengkomunikasikan pada orang-orang di sekitar mereka untuk ikut bergabung dalam komunitas ataupun hanya sekedar mengikuti kajian-kajian yang dilaksanakan oleh komunitas hijrah, termasuk pada suami masing-masing dan keluarga besar.

\section{Proses Interaksi dengan Komunitas Hijrah}

Manusia sebagai makhluk sosial tidak mungkin untuk tidak berinteraksi dengan manusia lain. Potensi-potensi yang dibawa manusia itu sejak lahir justru baru bisa berkembang dalam pergaulan hidup sesama manusia (Asti, 2019). Proses interaksi manusia, menurut Teori Interaksionisme Simbolik, tidak terdiri dari dua (atau lebih) komunikator yang perilakunya berkaitan dalam satu proses interaksi, dimana masing-masing komunikator kemudian memberikan stimulus dan lainnya merespon dengan cara sederhana. Interaksi harus dipahami sebagai suatu proses perkembangan dinamis, bukan hanya dialog antar dua komunikator saja.

Mead mendeskripsikan proses interaksionisme simbolik antar manusia biasanya melibatkan isyarat signifikan yang saling direspon oleh komunikator berdasarkan interpretasi mereka yang dilandasi oleh pengetahuan mereka tentang simbol konvensional dan makna yang diasosiasikan dengan interaksi tersebut. Isyarat signifikan ini kemudian menyebabkan orang lain perlu untuk memilih dari seperangkat kemungkinan makna guna menentukan tindakan apa yang selanjutnya harus dilakukan berdasarkan isyarat tersebut (Littlejohn \& Foss, 2016).

Proses interaksi yang dialami oleh informan AFA selama berinteraksi dalam komunitas hijrahnya, selain dalam bentuk dialog juga tampak terjadi interaksionisme simbolik, dimana ketika pada waktu itu AFA sempat mengeluhkan persoalan pendidikan anaknya, komunitas hijrahnya memberikan isyarat-isyarat signifikan bahwa seorang ibu adalah madrasah pertama bagi anak-anaknya. AFA kemudian memaknai hal tersebut sebagai sebuah pembulat keputusan bahwa dia harus berhenti dari pekerjaannya yang sekarang agar bisa mendidik anaknya dengan baik.

Senada dengan AFA, informan VS yang juga memutuskan untuk berhenti dari pekerjaannya setelah berhijrah menyatakan bahwa proses komunikasi yang terjadi dalam komunitas hijrahnya selalu membawa solusi bagi persoalan yang biasa ada dalam kehidupan sehari-harinya.

"Gimana ya, jadi kalo misalnya gue tu lagi galau ni ya kak waktu itu mau resign atau engga terus ngobrol sama temen-temen di komunitas tu rasanya vibes nya itu positif aja jadi gue tu dalam mengambil keputusan akhirnya dengan kepala dingin nih yang sebelumnya gue udah kayak mau meledak padahal kan. Sebenernya mereka tu ga yang bilang nyuruh resign eh perempuan tu haram kerja atau apa, tapi kayak yang bilang kalo tiang penyangga rumah tangga itu ya perempuan, seorang ibu, jadi ya gue setelah itu mikir kalo misal gue kerja dan anak di daycare kayak yang ga bisa mengawal tumbuh kembang anak gue ga sih." (VS 
2021, wawancara, tanggal 9 November 2021)

Proses interaksi kelompok yang ada di komunitas hijrah ini secara perlahan megarah pada groupthink atau pemikiran kelompok. Irving Janis (Littlejohn \& Foss, 2016) menyatakan bahwa ketika muncul keinginan kelompok untuk mempertahankan atmosfer yang kompak kemudian menyebabkan anggota merasa jangan sampai "mengganggu kenyamanan" atau "mengacaukan situasi". Ada beberapa karakteristik yang mendasari terjadinya groupthink, yaitu (1) kohesivitas, yaitu keterikatan antar anggota kelompok; loyalitas kelompok, (2) kesalahan struktural, mencakup pembatasan sumber informasi dan saran dari luar kelompok, dan homogenitas anggota kelompok, (3) konteks situasi provokatif, konteks yang menyebabkan tekanan pada anggota kelompok. Ketiga karakteristik tersebut ketika salah satu muncul akan mengarahkan kelompok pada groupthink (Littlejohn \& Foss, 2016).

Interaksi kelompok yang dilakukan oleh informan AFA dan VS dalam komunitas hijrahnya menunjukkan adanya kohesivitas yang moderat mengarah ke tinggi karena ketika berinteraksi langsung dengan orang-orang di komunitas hijrahnya, meski di luar acara kajian, mereka tetap berusaha untuk menunjukkan bahwa mereka sama dengan anggota komunitas hijrah lainnya misal dari segi pakaian dan perilaku sehari-hari. AFA mengaku jika dalam sehari-harinya terkadang tidak selalu dia menggunakan jilbab yang panjang dan lebar, namun ketika berkumpul atau sekedar bertemu dengan anggota-anggota komunitas hijrah dia akan menyesuaikan dengan mereka, mengenakan jilbab panjang dan lebar serta berkaus kaki. AFA menyatakan dia berperilaku demikian karena tidak ingin mengganggu kenyamanan anggota yang lain dengan perbedaan cara berpakaiannya.

Informan VS dalam proses interaksi dengan komunitas hijrahnya juga memiliki perasaan tidak mau mengganggu kenyamanan anggota lain, dalam hal ini selain pakain, VS juga berhenti untuk mendengarkan musik ketika tengah berinteraksi dengan anggotaanggota komunitas hijrahnya. Seperti halnya ketika VS pernah mengunggah story di salah satu media sosialnya mengenai acara kajian dan diberi backsound musik, kemudian beberapa anggota mengingatkan bahwa musik itu dalam pandangan komunitas mereka adalah sesuatu yang haram. Sehingga VS kemudian menghapus story tersebut dan tidak ingin kejadian serupa berlangsung ia kemudian memilih mendengarkan musik ketika sedang tidak bersama anggota-anggota komunitas hijrah yang lain.

Beberapa kohesivitas yang terjadi, meski sifatnya moderat namun bisa mengarah pada groupthink yang memiliki konsekuensi negatif, yang mana akan membuat individu semakin tidak nyaman dengan dirinya sendiri dalam situasi kelompok. Selain itu, tingginya kohesivitas juga akan meminimkan adanya pandangan atau pendapat dari anggota kelompok yang berbeda dari anggota lainnya, karena dalam proses interaksi kelompok yang baik, harus ada anggota kelompok yang berperan sebagai penentang sehingga proses interaksi dapat berjalan sehat (West \& Turner, 2019).

\section{Hijrah sebagai Gaya Hidup}

Gaya hidup atau yang sering dikenal sebagai lifestyle mencerminkan kepribadian seseorang yang berinteraksi dengan lingkungan. Gaya hidup merupakan pola hidup 
seseorang yang terlihat dari kegiatan, selera, dan pendapatnya dalam hal pembelanjaan uang dan pengalokasian waktu (Chaney, 1996). Menurut Chaney, seseorang menggunakan gaya hidup dalam kehidupan sehari-harinya untuk menjelaskan kompleksitas identitasnya. Dalam hal ini, membentuk gaya atau style untuk membangun identitas dalam suatu kelompok sosial tertentu menjadi hal yang penting dalam kehidupan masyarakat pada umumnya, termasuk pada informan AFA dan VS.

Informan AFA menyatakan bahwa setelah gaya hidup yang dia adopsi dari komunitas hijrahnya kemudian terbawa dalam kehidupan sehari-hari. Selain dia memutuskan berjilbab secara konsisten (tidak lepas pakai), dia juga memutuskan untuk berhenti dari pekerjaanya dan menjadi freelancer di komunitas hijrahnya. Selain itu saat ini dia juga tergabung dalam sebuah start-up milik salah satu anggota komunitas hijrah dan menjadi pengelola di sana. Dalam hal ini, bagi AFA hijrah bukan hanya sekedar perilaku dalam beribadah saja, mengikuti kajian saja, melainkan juga bagaimana kemudian dia berusaha untuk menerapkan ajaran-ajaran agamanya dalam kehidupan sehari-hari. Ketika dalam ajaran agamanya disampaikan bahwa ibu adalah madrasah pertama bagi anak-anaknya dan AFA berhenti bekerja, maka dia telah menerapkan hijrah itu sendiri sebagai gaya hidupnya. Dimana kemudian dia fokus untuk mendidik anak dan mengaktualisasi diri dengan kegiatankegiatan dalam circle komunitas hijrahnya.

Lebih lanjut lagi, gaya hidup seseorang merupakan sesuatu yang tercipta karena atau sesuai dengan status sosialnya dalam masyarakat. Perwujudan dari gaya hidup dan status sosial adalah adanya interaksi sosial, karena cara seseorang dalam berinteraksi sosial sangat dipengaruhi oleh gaya hidup dan status sosialnya (Pambayun, 2013). Hal ini terlihat dari interaksi yang dilakukan oleh AFA dan VS yang pada awal mula berhijrah adalah berasal dari interaksi dengan lingkungan sosial terdekat mereka, yaitu keluarga.

Gaya hidup sendiri biasanya akan tercermin dengan simbol-simbol tertentu, seperti merk yang digunakan sehari-hari dan segala sesuatu yang berhubungan serta dapat menunjukkan tingkat status sosial tertentu. Proses hijrah yang dialami oleh informan AFA dan VS membuat mereka kemudian menampilkan simbol-simbol tertentu untuk menunjukkan bahwa mereka telah lebih baik dari segi agama. Penggunaan-penggunaan kata-kata dalam bahasa Arab yang sering digunakan dalam komunikasi sehari-hari dan juga dalam unggahan di media sosial menunjukkan adanya perubahan gaya hidup yang mengarah ke lebih baik sesuai versih hijrah mereka.

\#HaykelAtharrazka
View all 2 comments

Gambar 1. Caption unggahan media sosial AFA sebelum berhijrah (Adeline, 2018)

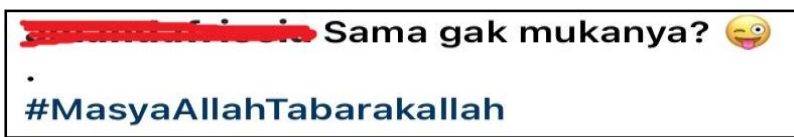

Gambar 2. Caption unggahan media sosial AFA setelah berhijrah (Adeline, 2019)

Penggunaan tagar dengan perbedaan yang signifikan terlihat pada unggahan AFA di media sosialnya pada saat sebelum dan setelah berhijrah. Kedua gambar merupakan caption dari unggahan foto AFA bersama anaknya, pada gambar pertama ketika AFA belum 
berhijrah, dia menggunakan tagar yang umum seperti nama anaknya. Pada gambar kedua pasca hijrah dia lebih memilih menggunakan tagar bernuansa islami. Hal ini merupakan bentuk perubahan gaya hidup dalam pemilihan simbol-simbol bahasa yang digunakan dalam kehidupan sehari-hari.

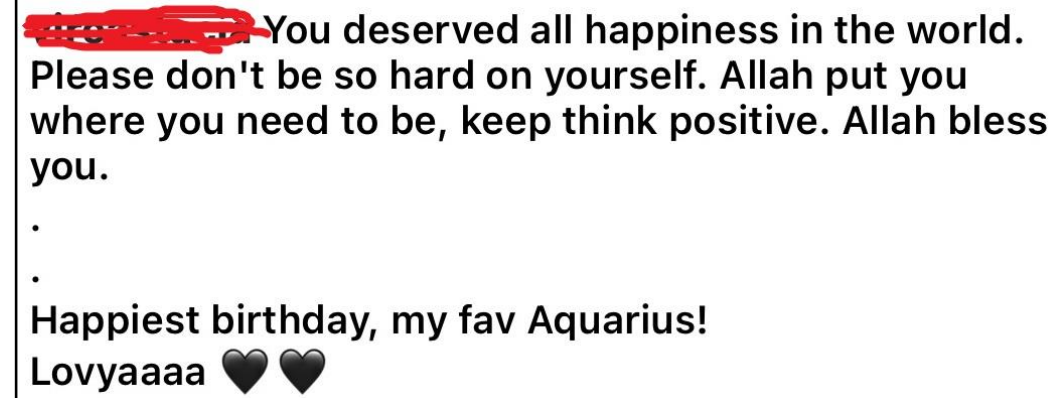

Gambar 3. Caption unggahan media sosial VS sebelum berhijrah (Stacia, 2018)

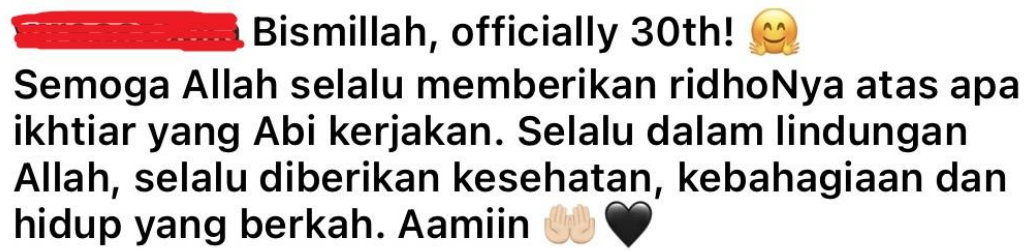

Gambar 4. Caption unggahan media sosial VS setelah berhijrah (Stacia, 2021)

Senada dengan AFA, informan VS juga melakukan perubahan gaya hidup pasca berhijrah dengan menonjolkan simbol-simbol islami dalam unggahan media sosialnya. Pada gambar pertama terlihat bahwa ketika suaminya berulang tahun, VS menuliskan ucapan dengan gaya kebarat-baratan dengan penggunaan bahasa Inggris, sedang pada gambar kedua lebih banyak istilah saduran dari bahasa Arab seperti ikhtiar, ridho, dan tak lupa menyebutkan Allah, bernuansa Islami.

Perubahan gaya hidup pasca berhijrah yang dialami oleh kedua informan merupakan hal yang wajar terjadi dalam proses interaksi antar manusia. Dalam proses komunikasi, gaya hidup sendiri dipengaruhi oleh keterlibatan seseorang dalam kelompok sosial, yang mencakup proses interaksi dan merespon berbagai stimulus yang diberikan oleh kelompok sosial tersebut (Pambayun, 2013).

\section{SIMPULAN}

Perubahan gaya hidup masyarakat pasca tergabung dalam kelompok sosial tertentu mengakibatkan terjadinya perubahan gaya hidup. Penelitian terhadap pelaku hijrah dalam artikel ini memperlihatkan adanya hal positif dan negatif dalam gaya hidup yang diadopsi seseorang setelah berhijrah.

Penelitian ini menemukan bahwa para informan yang merupakan digital native urban mengawali proses hijrahnya dari lingkungan sosial terdekat mereka, yaitu keluarga. Proses komunikasi yang mereka lakukan dengan lingkungan sosial selama proses berhijrah berlangsung lancar dan menuai tanggapan yang positif. Begitupun dengan proses interaksi informan dengan komunitas hijrah mereka yang dirasa membantu mengembangkan kualitas 
hidup informan. Meskipun demikian, terlihat adanya kohesivitas dalam taraf moderat yang dialami oleh informan dengan komunitas hijrahnya dimana informan pada waktu-waktu tertentu merasa perlu membatasi pendapat atau dirinya dalam proses interaksi dengan komunitasnya. Pengadopsian hijrah sebagai gaya hidup tentunya dilakukan oleh kedua informan dalam penelitian ini. Mulai dari gaya hidup sehari-hari seperti berpakaian, berbahasa, hingga dalam pemilihan jalan hidup seperti memutuskan untuk mendidik anak di rumah dan berhenti dari pekerjaannya.

\section{DAFTAR RUJUKAN}

Adeline, A. F. (2018). No Title. Instagram. https://www.instagram.com/p/BgeDGM_1T0kbZAz2oi97tg84CYXfQXcFQQsvos0/

Adeline, A. F. (2019). No Title. Instagram. https://www.instagram.com/p/Byc7mMRHV7VjEBXPD-tJs4fUCgGXxkPk5gCQk0/

Adlin, A. (1997). Desain, Teknologi, Gaya Hidup: Perangkat Elektronik sebagai Simbol Status Sosial. In Lifestyle Ecstasy: Kebudayaan Pop dalam Masyarakat Komoditas Indonesia. Jalasutra.

Ahmadi. (2009). Psikologi Umum. Rineka Cipta.

Asrianti, S. (2019). Ini Cara Merawat Rambut Untuk Perempuan Berhijab. Republika.Co.Id. https://republika.co.id/berita/pop33v459/ini-cara-merawat-rambut-untuk-perempuanberhijab

Asti, I. T. (2019). Paradigma Psikologi Komunikasi Dalam Upaya Pembentukan Kepribadian Muslim Dalam Lingkup Individu Dan Sosial. Jurnal Komunika Islamika : Jurnal Ilmu Komunikasi Dan Kajian Islam, 6(1). https://doi.org/10.37064/jki.v6i1.5520

Aurelia, J. (2019). Merebut Ambisi Hijrah Lewat K-Pop hingga Hapus Tato. Tirto.Id. https://tirto.id/merebut-ambisi-hijrah-lewat-k-pop-hingga-hapus-tato-d5lb

Chaney, D. (1996). Lifestylers: Sebuah Pengantar Komprehensif. Jalasutra.

Creswell, J. W. (1998). Qualitative inquiry and research design: Choosing among five traditions. In Qualitative Health Research.

Crozier, G., Denzin, N., \& Lincoln, Y. (1994). Handbook of Qualitative Research. British Journal of Educational Studies. https://doi.org/10.2307/3121684

DeVito, J. a. (2008). The Interpersonal Communication Book. PsycCRITIQUES.

Fajriani, S. W. (2019). HIJRAH ISLAMI MILENIAL BERDASARKAN PARADIGMA BERORIENTASI IDENTITAS. Sosioglobal : Jurnal Pemikiran Dan Penelitian Sosiologi. https://doi.org/10.24198/jsg.v3i2.21643

Frank, A. W., \& Riggins, S. H. (1992). Beyond Goffman: Studies on Communication, Institution, and Social Interaction. Canadian Journal of Sociology / Cahiers Canadiens de Sociologie. https://doi.org/10.2307/3341221

Hall, E. T. (1989). Beyond Culture. Anchor Books.

Hariyani. (2017). Pola Konsumsi Berita Online: Generasi Digital Native dan Digital Immigrant di Indonesia. 148-160.

Jamaludin, A. N. (2015). Sosiologi Perkotaan: Memahami Masyarakat Kota dan Problematikanya. In CV Pustaka Setia.

Littlejohn, S. W., \& Foss, K. A. (2016). Ensiklopedia Teori Komunikasi. KENCANA.

Meiranti, M. (2019). FENOMENA HIJRAH DI ERA MILENIAL DALAM MEDIA SOSIAL. Ath Thariq Jurnal Dakwah Dan Komunikasi. https://doi.org/10.32332/ath_thariq.v3i2.1350 
Nurlatifah, E. (2019). Jilbab dan Islam Indonesia Masa Order Baru 1982-1991. UIN Syarif Hidayatullah Jakarta.

Pambayun, J. G. (2013). Social Climbing Sebagai Aktualiasasi Diri Kaum Marjinal (Studi Deskriptif Di Kalangan Remaja Jakarta Selatan). Journal of Chemical Information and Modeling, 53(9).

Sholihah, Di. R. (2019). Trend berhijrah dikalangan Muslim Milenial: Kajian Ma'ani al Hadith dalam Kitab Sunan al-Nasa'i Karya Imam Nasa'i Nomor Indeks 4996. Universitas Islam Negeri Sunan Ampel Surabaya.

Stacia, V. (2018). No Title. Instagram. https://www.instagram.com/p/BeSgOcpF78RMVsVT9ZYKciGvQ944STfgPdtbrg0/

Stacia, V. (2021). No Title. Instagram. https://www.instagram.com/p/CKYmAd5hJSB6tOrIfKlynD53nuT-hbyKPqBVlA0/

Susanti. (2020). Sensus Penduduk 2020, Sensus Era Digital. Republika.Co.Id. https://republika.co.id/berita/q3qglj284/sensus-penduduk-2020-sensus-era-digital

West, R., \& Turner, L. H. (2019). Introducing Communication Theory. In Making Sense of Messages.

Widhana, D. H. (2019). Tren Hijrah Anak Muda: Menjadi Muslim Saja Tidak Cukup. Tirto.Id. https://tirto.id/tren-hijrah-anak-muda-menjadi-muslim-saja-tidak-cukup-ds9k

Wijaya, L. D. (2018). Hasil Survei KedaiKOPI Soal Penggunaan Cadar dan Sebutan Kafir. Tempo.Co. https://nasional.tempo.co/read/1091202/hasil-survei-kedaikopi-soalpenggunaan-cadar-dan-sebutan-kafir/full\&view $=$ ok

Wirman, W. (2016). Citra dan Presentasi Tubuh. Alaf Riau.

Yasya, W., \& Nurhaliza, W. O. S. (2021). DIGITALISASI HIJRAH MELALUI KOMUNITAS VIRTUAL. Journal Education and Development, 9(3). 